\title{
Resilience of commercial banks of Bangladesh to the shocks caused by COVID-19 pandemic: an application of MCDM-based approaches
}

An application of MCDMbased approaches

\author{
Ratan Ghosh
}

Department of Business Administration in Accounting and Information Systems, Bangladesh University of Professionals, Dhaka, Bangladesh, and

Farjana Nur Saima

Faculty of Business and Social Science, Bangladesh University of Professionals, Dhaka, Bangladesh

\begin{abstract}
Purpose - The purpose of this study is to analyze and forecast the financial sustainability and resilience of commercial banks of Bangladesh in response to the negative effects of COVID-19 pandemic.

Design/methodology/approach - Eighteen publicly listed commercial banks of Dhaka Stock Exchange (DSE) have been taken as a sample for this study. To measure the riskiness of banks' credit portfolio, nine industries of DSE have been considered to determine probable loss of revenue arising from the COVID-19 pandemic shock. Moreover, two commonly used multiple-criteria-decision-making (MCDM) tools namely TOPSIS method and HELLWIG method have been used for analyzing the data.

Findings - Based on the performance scores under TOPSIS and HELLWIG method, banks are categorized into three groups (six banks each) namely top resilient, moderate resilient and low resilient. It is found that EBL and DBBL are the most resilient banks, and ONEBANK is the worst resilient bank in Bangladesh in managing the COVID-19 pandemic shock.

Research limitations/implications - This study concludes that banks with low capital adequacy, low liquidity ratio, low performance and higher NPLs are more vulnerable to the shocks caused by the COVID-19 pandemic. The management of commercial banks should emphasize on maintaining higher capital base and reducing default loans.

Originality/value - Resilience of the Bangladeshi banking sector under any adverse economic event has been examined by only using stress testing approach. This study is empirical evidence where both TOPSIS and HELLWIG MCDM methods have been used to make the result conclusive.
\end{abstract}

Keywords Resilience, Commercial banks, COVID-19, MCDM, Bangladesh

Paper type Research paper

\section{Introduction}

Outbreak of any global pandemic has a serious impact on human health, economy, education, environment and so on. The outbreak of COVID-19 pandemic has already affected the global economy adversely (McKibbin and Fernando, 2020). Like other pandemics, the COVID-19 pandemic can bring recession or depression for an economy, as businesses are not able to run in full capacity due to strict lockdown period and restricted movement, which will result in a

(C) Ratan Ghosh and Farjana Nur Saima. Published by Emerald Publishing Limited. This article is published under the Creative Commons Attribution (CC BY 4.0) licence. Anyone may reproduce, distribute, translate and create derivative works of this article (for both commercial and non-commercial purposes), subject to full attribution to the original publication and authors. The full terms of this licence

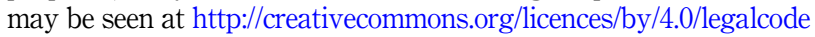

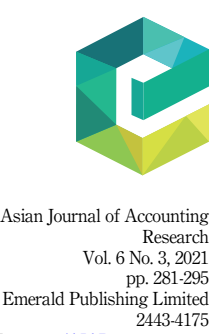

Received 26 October 2020 Revised 28 November 2020 15 December 2020 
AJAR 6,3

\section{2}

Table 1.

List of diagnostic variables substantial decline in aggregate demand, production, foreign trade, sales capacity and so on. Financial institutions will face severe problems because of its credit exposure to different industries. Crisis in the financial sector, particularly in the banking industry, will cause economic disturbances and instability. From the confrontation of global financial turmoil in 2008, the sustainability of the banking industry has been emphasized globally. Consequently, Bangladesh Bank, the central bank of Bangladesh and the regulatory body of the banking industry of Bangladesh, had issued a macro-prudential guideline in 2010 for using stress testing approach to assess the resilience of banks in managing any kind of adverse economic shocks. The main objective of this kind of macro-prudential policy is to avoid distress for banking companies (Nakatani, 2020) (see Tables 1 and 2)

As an emerging economy, Bangladesh has been able to maintain an impressive economic growth over the last decade. For the Fiscal Year (FY) 2019-2020, the expected growth rate of gross domestic product (GDP) was $8.20 \%$ in Bangladesh, but this expectancy has been hampered by the adverse effect of the COVID-19 pandemic, particularly in the last quarter of FY 2019-20 (Ministry of Finance, 2019). The economic disruptions caused by this pandemic will lower the economic growth of Bangladesh for FY 2019-20 as forecasted by World Bank (2-3\%), Asian Development Bank (4.5\%) and International Monetary Fund (3.8\%). The stability of financial institutions works as a blessing for an economy to grow sustainably. However, the Bangladeshi banking system is facing a severe problem due to the intensifying growth of non-performing loans (NPLs). Skyrocketing NPLs is also creating doubt in depositors' minds and depositors' do not feel secured to deposit money in the banks which

\begin{tabular}{|c|c|c|c|}
\hline $\begin{array}{l}\text { Diagnostic } \\
\text { variable }\end{array}$ & Symbol & Description & $\begin{array}{l}\text { Variable } \\
\text { profile }\end{array}$ \\
\hline Capital adequacy & $\mathrm{Z1}$ & $\begin{array}{l}\text { Tier-1 capital to risk-weighted } \\
\text { assets (RWA) }\end{array}$ & S \\
\hline $\begin{array}{l}\text { Short term } \\
\text { liquidity }\end{array}$ & $\mathrm{Z2}$ & $\begin{array}{l}\text { The ratio between current assets and current liability aging } \\
\text { within } 30 \text { days }\end{array}$ & $\mathrm{S}$ \\
\hline Profitability & Z3 & Return on average equity & $\mathrm{S}$ \\
\hline $\begin{array}{l}\text { Credit portfolio } \\
\text { quality }\end{array}$ & $\mathrm{Z4}$ & Share of non-performing loans (NPLs) to total loans & $\mathrm{D}$ \\
\hline $\begin{array}{l}\text { Resilience } \\
\text { capacity }\end{array}$ & Z5 & $\begin{array}{l}\text { The ratio of risk measured credit exposure in different } \\
\text { industrial sectors affected by COVID-19 pandemic-- } \\
\text { "Option 1" } \\
\text { Rates of return of individual sectors of the economy in 1st } \\
\text { Quarter of } 2020 \text { on Dhaka Stock Exchange- "Option 2" }\end{array}$ & $\begin{array}{l}\text { "Option 1"-D } \\
\text { "Option 2"-S }\end{array}$ \\
\hline
\end{tabular}

Table 2.

Risk measures of nine industrial sectors in Bangladesh economy in the context of COVID-19

\begin{tabular}{|c|c|c|c|c|c|}
\hline & Name of industries & $\begin{array}{l}\text { Risk level (loss of } \\
\text { revenue) }\end{array}$ & $\begin{array}{l}\text { Risk level } \\
\text { (export) }\end{array}$ & $\begin{array}{l}\text { Risk level } \\
\text { (import) }\end{array}$ & $\begin{array}{c}\text { Weighted risk } \\
\text { measures }\end{array}$ \\
\hline 1 & Food and allied & Low & High & Significant & 1.8 \\
\hline 2 & Fuel and power & Significant & Low & Low & 2.4 \\
\hline 3 & $\begin{array}{l}\text { Pharmaceuticals and } \\
\text { chemicals }\end{array}$ & High & Low & Significant & 3.3 \\
\hline 4 & IT & Low & Moderate & Low & 1.2 \\
\hline 5 & Engineering & Significant & Moderate & High & 2.9 \\
\hline 6 & Textile & Moderate & High & High & 2.6 \\
\hline 7 & Cement & High & Low & Low & 3.1 \\
\hline 8 & Services and real estate & Moderate & Significant & Moderate & 2.2 \\
\hline 9 & Travel and leisure & Low & Significant & Moderate & 1.5 \\
\hline
\end{tabular}


results in liquidity crisis for banks. On top of that, the capped interest rate regime from 2020 is also putting the potential threat of low profitability for banks. Moreover, these irregularities in the banking industry of Bangladesh are also raising a question about the management quality of the banking industries.

Along with the existing problems in the banking industry of Bangladesh, the COVID-19 pandemic will certainly deteriorate the profitability of the banks because of withdrawal of deposits by depositors' combating the crisis period, less deposit collection from clients and deferral of revenue collection, as many businesses were closed for a long time during strict lockdown period (More than 9 weeks). Though banks are reporting and disclosing profits in the interim financial statements, interest income is not received in many cases, as Bangladesh Bank has extended the loan moratorium till December 2020 (Bangladesh Bank, 2020). This kind of restriction by Bangladesh Bank will create a cash shortage in banks. To what extent the COVID-19 pandemic will affect the banking industry of Bangladesh is yet to be discovered. Recently, Barua and Barua (2020) conducted a study using stress testing approach suggested by Bangladesh Bank to assess banking sector's resilience considering different shocks scenarios. The authors predicted substantial NPLs shocks from mainly two export-oriented industries: Ready Made Garments (RMGs) industry and small and medium enterprises (SME) during the COVID-19 pandemic since one-third of the total outstanding loan of banking industry is tied to those industries combined.

However, this study will try to forecast the probable scenario of the adverse effects of the COVID-19 pandemic in the banking industry of Bangladesh considering banks' credit exposure to several industries, which are most likely to be impacted by the negative effects of this pandemic. The riskiness of all the industries may not be same during the pandemic. So, to make realistic forecasting, industries are classified into three categories: less risky, moderate risky and high risky. This classification has been done based on microeconomic and macroeconomic analysis done by various experts, brokerage houses and think-tanks (LankaBangla, 2020; Asian Tiger Capital, 2020; The Business Standard, 2020; Hossain, 2020; World Bank, 2020b). Assessing the performance scores of 18 publicly listed commercial banks of DSE under TOPSIS and HELLWIG method, EBL and DBBL are found to be the most resilient banks, and ONEBANK is the worst resilient bank in Bangladesh in managing the COVID-19 pandemic shock.

The remainder of the manuscript is organized as follows. Section 2 outlines the literature review related to the study. Section 3 describes the research method including research design, sample, data analysis technique and measure. Section 4 presents the finding of this study and the interpretation of the results. Finally, some policy recommendations and limitations have been discussed in Section 5.

\section{Literature review}

\subsection{Resilience and business}

The term "resilience" has been defined in different perspectives. The socio-ecological theory considers a system to be resilient if that system can function well even after facing disturbances. From a business point of view, Reeves and Whitaker (2020) describe resilience as the adaptive power of a company to the financial stress situation and to flourish in changed circumstances. The term "resilience" is also prominent in the banking sector. According to Basel Committee's report, a resilient banking sector refers to its strong capacity to withstand shocks resulting from different financial and economic crises (Bank for International Settlements, 2009a).

\subsection{Financial crisis and resilience of banking sector}

Financial intermediation process was hampered after the global financial crisis in 2008 . The turmoil in the financial intermediation process shook the confidence of depositors, and they 
AJAR 6,3

284

started withdrawing their savings massively, which exaggerated the already worsened financial condition of the banking sector. Consequently, the Basel Committee proposed to maintain quality capital base, sufficient risk coverage for counterparty type credit exposures, supplementary leverage ratio, capital buffer and provision based on expected loss model instead of incurred loss model (Bank for International Settlements, 2009b). The objective of the Basel Committee was to prepare the banks as a resilient system to tackle any upcoming stress. While investigating the determinants of a resilient banking system, Huang and Ratnovski (2009) postulated that funding structure, low capital ratio and low liquidity ratio were strong determinants for Canadian banks to remain resilient during the 2008 financial crisis. Similarly, Han and Melecky (2013) argued banks with more diversified deposits base could be more resilient during financial crisis, and thus broader financial inclusion should be prioritized in policy formulation. Conversely, Bakir (2013) argued that due to the dynamic nature of risk, only capital adequacy-based regulation is not sufficient to build a safe banking system. However, financial bubble or any global systematic financial crisis is contagious like any kind of pandemic which bring adverse condition for the banking sector and so the development of resilience system in both cases may be similar (Shiller, 2020).

\subsection{COVID-19 pandemic and banking sector}

The COVID-19 pandemic may cause a great recession in an economy, as it will increase unemployment problem which will decrease savings and investment as well (World Bank, 2020a). Consequently, this pandemic will create the risk of massive withdrawal of savings, risk of increased default rates, low growth of loan and investment, low-interest income and high possibility of bankruptcy risk (World Bank, 2020b; Goodell, 2020). Moreover, it will be tough for developing countries to recover immediately from the shocks of the COVID-19 pandemic because of weak institutional governance, underdeveloped capital market and bureaucratic problems in policy formulation (Görg et al., 2020; Wilson, 2020). Aldasoro et al. (2020) concluded that banks with a good capital base and high profitability would perform relatively smoothly during the pandemic. Korzeb and Niedziółka (2020) found larger banks are more resilient to the negative impact of the pandemic while researching on the Polish banking sector. On contrary, Barua and Barua (2020) found that larger banks are more vulnerable during the pandemic in the context of Bangladesh. They conducted a study on the Bangladeshi banking sector using stress testing approach and found that all banks in Bangladesh might experience a reduction in risk-weighted asset, capital adequacy ratio and interest revenue due to different macroeconomic shocks caused by the COVID-19 pandemic. Regardless of the financial threats posed by the pandemic, some authors also drew attention to rapid digitalization of banking sector, formulating quality and dynamic market portfolio, expected loss calculation and creditor quality assessment (Bryan et al., 2020; Selvan and Vivek, 2020).

Although Barua and Barua (2020) studied the adverse effect of the COVID-19 pandemic on banking sector of Bangladesh, they could not work with whole/maximum portion of credit portfolio of the banks. They just focused on two large industries RMG and SME industry. However, this pandemic has affected export-oriented industries, service industries and manufacturing industries of Bangladesh. As most of the banks' credit portfolio is diversified, so the adverse effect of the COVID-19 pandemic will ultimately hit the performing loan of banking industry. To investigate the resilience of financial sector of Bangladesh, this study will analyze the strength of banks' credit portfolio by considering banks' credit exposure to the industries, which are most likely to be impacted by these negative effects of the COVID-19 pandemic. 


\section{Research methodology}

\subsection{Sample selection}

Among 30 publicly listed private commercial banks in DSE, 18 banks have been taken as sample. The remaining listed banks could not be included in the sample size because of the variation in the disclosure of the sector-wise loan classification in the annual reports.

\subsection{Data collection}

Firm specific data have been collected from annual reports of sampled banks. For predicting revenue growth of various industries in the COVID-19 pandemic, publicly listed nine industries of DSE have been considered.

\subsection{Data analysis technique}

Multiple-criteria decision-making (MCDM) method has been used for analyzing banks' resilience to the potential risks caused by the COVID-19 pandemic. MCDM method is a complex decision-making tool that enables to undertake various aspects to take a meaningful decision by prioritizing or choosing between options (Mousavi-Nasab and Sotoudeh-Anvari, 2017). In this study, TOPSIS and HELLWIG method are used as linear ordering model.

3.3.1 TOPSIS model. TOPSIS stands for "Technique for Order Preference by Similarity to Ideal Solution". TOPSIS is one of the mostly used MCDM tools for decision-making under any kind of complex situation. Roy and Das (2018) argued TOPSIS model is also viable in explaining the financial performance of banks. Steps of ranking and ordering decision under TOPSIS model:

Step 1: Standardization of diagnostic variables, $z_{i j}=\frac{x_{i j}}{\sqrt{\sum_{i=1}^{n} x_{i j}^{2}}}$ Where, $x_{i j}$ - observation of the $j$-th variable for the object $i$.

Step 2: Calculating the best object $\left(z_{j}^{+}\right)$for a stimulant and the worst object $\left(z_{j}^{-}\right)$for a destimulant of diagnostic variable: $z_{j}^{+}=\max _{j}\left(Z_{i j}\right) \quad z_{j}^{-}=\min _{j}\left(Z_{i j}\right)$

Step 3: Calculating Euclidean distance of objects from the best object and the worst object:

$$
d_{i}^{+}=\sqrt{\sum_{j=1}^{m}\left(z_{i j}-z_{j}^{+}\right)^{2}}, \quad d_{i}^{-}=\sqrt{\sum_{j=1}^{m}\left(z_{i j}-z_{j}^{-}\right)^{2}}
$$

Step 4: Calculating performance score, $q_{i}=\frac{d_{i}^{-}}{d_{i}^{+}+d_{i}^{-}}$[whereby, typically interval of $q_{i}$ is $\left.(0,1)\right]$ 3.3.2 HELLWIG model. HELLWIG method is a linear ordering model which enables to create ordering and ranking objects based on multiple variables (Fura and Wang, 2017). This method is proposed by professor Zdzislaw Hellwig (1968). Steps of HELLWIG methods are:

Step 1: Standardization of diagnostic variables, $z_{i j}=\frac{x_{i j}-\bar{x}_{j}}{S\left(x_{j}\right)}$

Where, $x_{i j}$ - observation of the $j$-th variable for the object $i$.

$\bar{x}_{j}$ - the mean value of $j$-th variable; $S\left(x_{j}\right)$ - the SD of $j$-th variable

Step 2: Determination of the best values to get development pattern, $z_{j}^{+}=\left\{\begin{array}{l}\max _{j}\left(z_{i j}\right) \\ \min _{j}\left(z_{i j}\right)\end{array}\right.$ Where, $z_{j}^{+}$- the best values (maximum for stimulant and minimum for destimulant)

Step 3: Calculating Euclidean distance from the development pattern, $d_{i}^{+}=\sqrt{\sum_{j=1}^{m}\left(z_{i j}-z_{j}^{+}\right)^{2}}$

Step 4: Calculating value of the Hellwig synthetic indicator of development,
An application of MCDMbased approaches

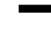


AJAR

6,3

286

$q_{i}=1-\frac{d_{i}^{+}}{d_{0}}$ [whereby, typically interval of $q_{i}$ is $\left.(0,1)\right]$

Where, $d_{i}^{+}$- the Euclidean distance of the variable from development pattern

$d_{0}$ - the dispersion of object from the development pattern, $d_{0}=\bar{d}_{0}+2 S_{d}$

Where, $\bar{d}_{0}$ - the average distance between object and development pattern, $\bar{d}_{0}=\frac{\sum_{i=1}^{n} d_{i}^{+}}{n}$

$S_{d^{-}}$the SD from average distance between object and development pattern,

$$
S_{d}=\sqrt{\frac{\sum_{i=1}^{n}\left(d_{i}^{+}-\bar{d}_{0}\right)^{2}}{n}}
$$

3.3.3 Weighting factors. TOPSIS and Hellwig are numerical methods of MCDM technique for which definition of quantitative weights for each criterion is required (Korzeb and Samaniego-Medina, 2019). There are three ways of defining weights to diagnostic variables: subjective approach, objective approach and integrated approach. For assigning relevant weights to the diagnostic variables of this study, both subjective and objective approach of weight distribution based on statistical procedure has been used in accordance with Korzeb and Samaniego-Medina (2019).

(1) System $\mathrm{w}_{1}$ : providing same weights for all the variables, $w_{k}=\frac{1}{m}$

Where, $k$ - indicator's number $(k=1,2, \ldots m)$

(2) System $\mathrm{w}_{2}$ : Generally, the weights are determined based on the expert method or in any specific variables that bear significant importance in the literature. In this study, more weights have been given in capital adequacy ratio and short-term liquidity ratio which may ensure resilience of banks in managing the COVID-19 pandemic crisis.

(3) System $\mathrm{w}_{3}$ : Weights are calculated based on the coefficient of variation.

$$
w_{k t}=\frac{\left|v_{k t}\right|}{\sum_{k=1}^{m}\left|v_{k t}\right|}
$$

Where, $v_{k t^{-}}$coefficient of variation $(k=1,2, \ldots m)$

\subsection{Measures}

To assess the resilience of the banking industry of Bangladesh in managing potential negative effects of the COVID-19 pandemic, five diagnostic variables have been used in this study. These variables are capital adequacy, liquidity ratio, profitability, non-performing loans and resilience capacity to adverse effects of the COVID-19 pandemic. The previous literature shows that capital adequacy, liquidity ratio and non-performing loans (NPLs) are commonly used in measuring the resilience of financial institutions (Maheswaran and Rao, 2014; Patra and Padhi, 2020). All the diagnostic variables are divided into two categories: stimulant (S) and destimulant (D). Stimulants (S) are the variables that will increase financial strength of a bank. Therefore, higher value of stimulants (S) is expected. Conversely, destimulants (D) are the variables that will weaken the financial strength of a bank. So, its lower value is expected. Moreover, capital to risk-weighted asset ratio (CRAR) is also used as a proxy of the $Z 1$ variable to check the consistency of findings.

Resilience of bank's investment portfolio (Z5 Variable) is determined by analyzing assessed banks' credit portfolio risk arising from its credit exposure to the industries which are highly 
exposed to the adverse economic shocks caused by the COVID-19 pandemic. However, the portfolio risk has been measured by two different alternatives: "Option 1" and "Option-2". Option 1: "Option -1" measures the portfolio risk by integrating the fall of revenue in 2020 due to the pandemic. In this study, the revenue has been forecasted by dividing the year 2020 into four major phases namely normal period, strict lockdown period, de-freezing period and refreezing period. Nine industries have been considered to determine probable loss of revenue arising from the COVID-19 pandemic shock. Based on the vulnerability of industries in the pandemic, all the industries are divided into three categories: less risky, moderate risky and high risky. However, food and allied business is categorized under less risky, as it was not severely affected during the pandemic. Moderate risky industries include fuel and power, IT, engineering and pharmaceuticals and chemicals. High-risky industries include textile industry, cement, real estate and travel and tourism. Revenue will not be the same in all industries, as different industries have different kinds of risk exposure in this pandemic. For example, in normal period no loss is counted, but less risky industries are assumed to have $20 \%$ loss, moderate risky industries are assumed to have 50\% loss, and high-risky industries are assumed to have $100 \%$ loss during strict lockdown period. Then, successively half of the previous period loss percentage is assumed to be lost in de-freezing and re-freezing period.

(1) Normal period: on March 8, 2020, the first case of COVID-19 was diagnosed in Bangladesh. To reduce the infection rate, general leave in the name of "lockdown" was declared from 26 March, 2020 by the Government of Bangladesh (GoB) (Shammi, 2020). Before the announcement of lockdown, businesses were performing their regular activities. Hence, the first 12 weeks (January 1 to March 25) of 2020 have been considered as normal period in this study.

(2) Strict lockdown period: from March 26, 2020 to May 30, 2020, a strict lockdown was maintained in Bangladesh. People stayed home amid the threat of COVID infection. Consequently, the economy was slowed down, as businesses were shut down for the threat transmission of virus in strict lockdown period. Except for general and emergency services, all the business firms were shutdown. In this study, forecasted revenue in strict lockdown period is 80,50 and $0 \%$, respectively, for less risk, moderate risk and high-risk industries.

(3) De-freezing period: after more than nine weeks of strict lockdown, the government had withdrawn lockdown on May 30, 2020 and permitted to reopen industries and business with proper safety measures from June 1, 2020. Lifting of lockdown had not helped the reviving of the economy, as the $\mathrm{GoB}$ was unable to flatten the curve of COVID-19 infection rate (Shammi, 2020). Followed by a growing case of COVID-19, businesses in Bangladesh were not getting the opportunity to get back on the regular track. June 1, 2020 to August 30, 2020 (12 weeks) is considered as de-freezing period in Bangladesh. In this study, it is estimated that less-risky industries will earn $90 \%$ revenue, moderate risky industries will earn $75 \%$ revenue and high-risky industries will earn $50 \%$ revenue of regular time.

(4) Re-freezing period: refreezing period is the timeline when the businesses are expected to run in full functionality. It is not certain how many days or years the COVID-19 pandemic will remain. But it can be expected that the economy will come to its normal course of action from September 2020. September 1, 2020 to December 31, 2020 is estimated as re-freezing period for overcoming shocks of the COVID-19 pandemic. In this time period, it is estimated that less-risky industries will earn 95\% revenue, moderate risky industries will earn $87.50 \%$ revenue and high-risky industries will be able to generate $75 \%$ revenue of regular time.
An application of MCDMbased approaches

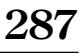


AJAR 6,3

288

3.4.1 Calculation of a bank's credit risk exposure (Z5) as "Option 1". If $R_{(t-1)}$ is the average annual revenue of an industry in year the 2019, then the expected annual revenue of the industry in 2020 will be $E\left(R_{t}\right)$. Hence, the average weekly revenue of 2019 (AW) in $(i)$ industries is,

$\mathrm{AW}_{i}=\frac{R_{i(t-1)}}{52}$ Where $i=1,2 \ldots \ldots m$

The projected revenue of $2020\left[E\left(R_{t}\right)\right]$ has been determined by multiplying percentage of revenue with $\mathrm{AW}_{i}$ according to risk category (less risky, moderate risky and high Risky) for (i) industries.

$$
\begin{aligned}
E\left(R_{i t}\right)= & \left(\mathrm{AW}_{i} \times 13 \text { Weeks } \times \mathrm{PR}_{i}\right)+\left(\mathrm{AW}_{i} \times 9 \mathrm{Weeks} \times \mathrm{PR}_{i}\right)+\left(\mathrm{AW}_{i} \times 12 \mathrm{Weeks} \times \mathrm{PR}_{i}\right) \\
& +\left(\mathrm{AW}_{i} \times 18 \text { Weeks } \times \mathrm{PR}_{i}\right)
\end{aligned}
$$

Where, $\mathrm{PR}_{i}$ - represents percentage of revenue under various risk categories of industries

Thus, the expected loss of revenue in 2020 due to shock arising from the COVID-19 pandemic can be determined,

$$
E\left(L_{i t}\right)=E\left(R_{i t}\right)-R_{i(t-1)}
$$

Furthermore, export $\left(E_{i(t-1)}\right)$ and import $\left(I_{i(t-1)}\right)$ value of $(i)$ industries are considered supplementary, as foreign trade is also hampered due to the COVID-19 pandemic. Finally, $E\left(L_{i t}\right), E_{i(t-1)}$ and $I_{i(t-1)}$ are classified by using quartile ranking to measure industry risk. The risk is measured as (1) Low - I Quartile, (2) Moderate - II Quartile, (3) Significant - III Quartile and (4) High - IV Quartile. Following the quartile ranking, weighted portfolio risk $\left(\mathrm{WPR}_{i t}\right)$ is calculated by assigning $20 \%$ weight to $E_{i(t-1)}, 10 \%$ weight to $I_{i(t-1)}$ and $70 \%$ of weight to $E\left(L_{i t}\right)$ (Korzeb and Niedziółka, 2020). So, weighted portfolio risk $\left(\mathrm{WPR}_{i t}\right)$ is:

$$
\mathrm{WPR}_{i t}=\left(\mathrm{QE}_{i(t-1)} \times 0.20\right)+\left(\mathrm{QI}_{i(t-1)} \times 0.10\right)+\left(\mathrm{QE}\left(L_{i t}\right) \times 0.70\right)
$$

Finally, riskiness $(Z 5)$ of a bank's portfolio loan $\left(\mathrm{PL}_{(t-1)}\right)$ resulting from loan exposure in different $(i)$ industries is measured:

$$
Z 5=\frac{\sum_{i=1}^{m}\left(\mathrm{PL}_{i(t-1)} \times \mathrm{WPR}_{i t}\right)}{\sum_{i=1}^{m} \mathrm{PL}_{i(t-1)}}
$$

Option 2: resilience of banks' portfolio loan has been measured by determining portion of performing loan in the portfolio. If $R_{i t}$ is the average rate of return on shares for the first quarter of 2020 as per listed companies of DSE, then average rate of return on share for each sample industry $(j)$ will be:

$$
\bar{R}_{j}=\frac{\sum_{i=1}^{n} R_{i j t}}{n_{j}} \quad[\text { where } i=1,2 \ldots n \text { and } j=1,2 \ldots m]
$$

Second, SD of return on shares has been used a proxy for measuring risk exposure of industries caused by potential adverse effects of the COVID-19 pandemic.

$$
\mathrm{SD}_{R_{j}}=\sqrt{\frac{\sum_{i=1}^{n}\left(R_{i j t}-\bar{R}_{j}\right)^{2}}{n_{j}-1}}
$$

If a bank has $\mathrm{PL}_{(t-1)}$ portfolio loan in different $(j)$ industries, $\mathrm{PL}_{j(t-1)}$ will be impaired to the extent of risk arising amid the COVID-19 pandemic. So, expected impairment of portfolio loan is: 


$$
E\left(L_{j t}\right)=\mathrm{PL}_{j(t-1)} \times \mathrm{SD}_{R_{j}}
$$

An application

Finally, balance of $\mathrm{PL}_{j(t-1)}$ is calculated as follows:

$$
\mathrm{PL}_{j t}=1-\frac{E\left(L_{j t}\right)}{\mathrm{PL}_{j(t-1)}}
$$

Thus, the projected balance of portfolio loan $\mathrm{PL}_{j t}$ in 2020 has been considered as the values for variable $\mathbf{Z 5}$.

\section{Results}

This paper has investigated the resilience of publicly listed private commercial banks of Bangladesh in managing the shocks arising from the COVID-19 pandemic. TOPSIS and HELLWIG MCDM methods have been used for analyzing data. This study has considered ranking scores of $1-6$ as top score, $7-12$ as moderate score and 13-18 as lowest score to identify the most, the moderate and the least resilient banks during the pandemic. Each bank was then classified into any of the three categories in which it's score is maximum. Though the rankings of all banks are close to each other under three weighting factors in both ranking methods, ranking of some banks has varied amongst the top to the moderate to the lowest scores. The result clearly shows in TOPSIS and HELLWIG method considering three weighting factors (Figures 1 and 2).

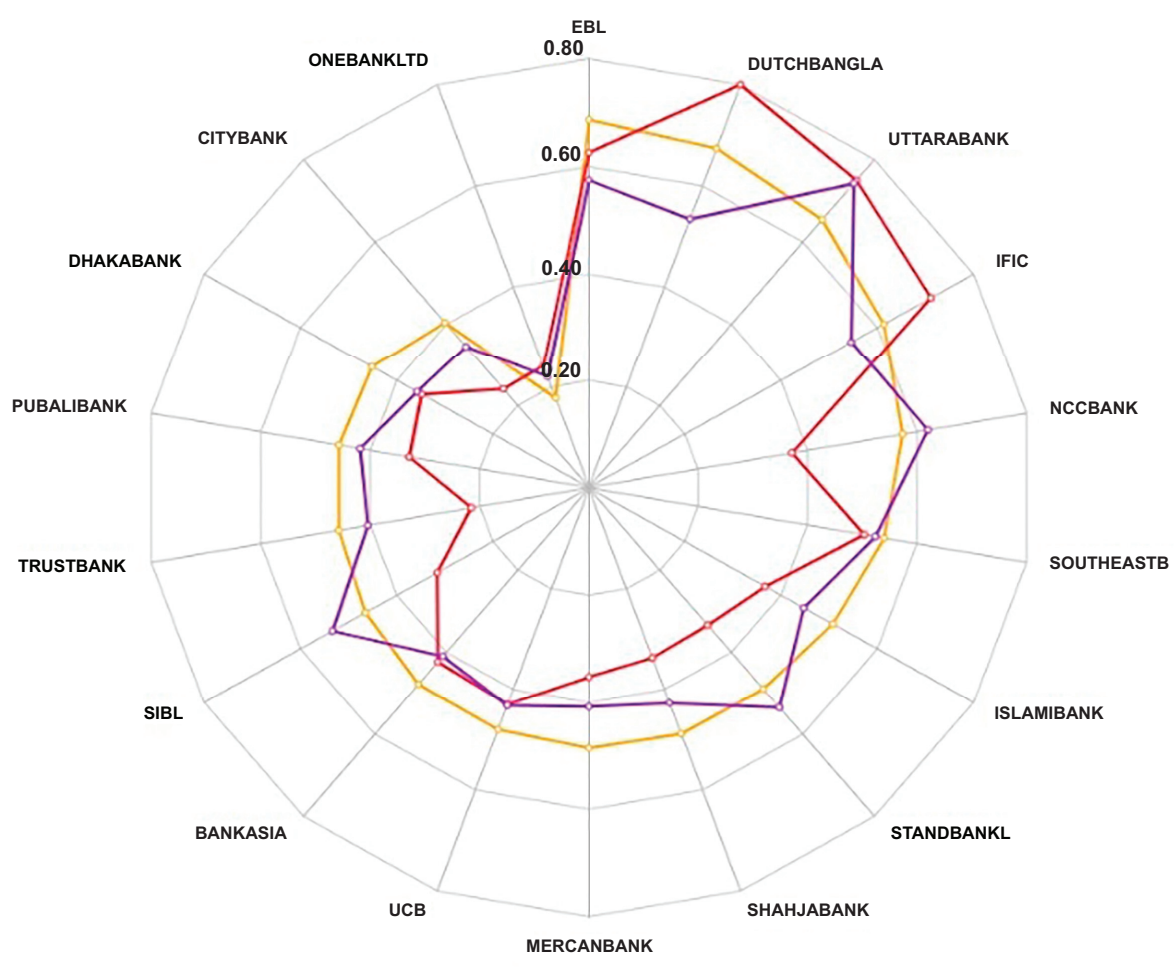

Figure 1.

Resilience of assessed banks under-option 1 and TOPSIS method 


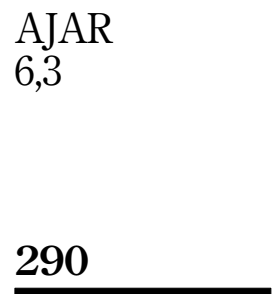

Figure 2.

Resilience of assessed banks under-option 1 and HELLWIG method

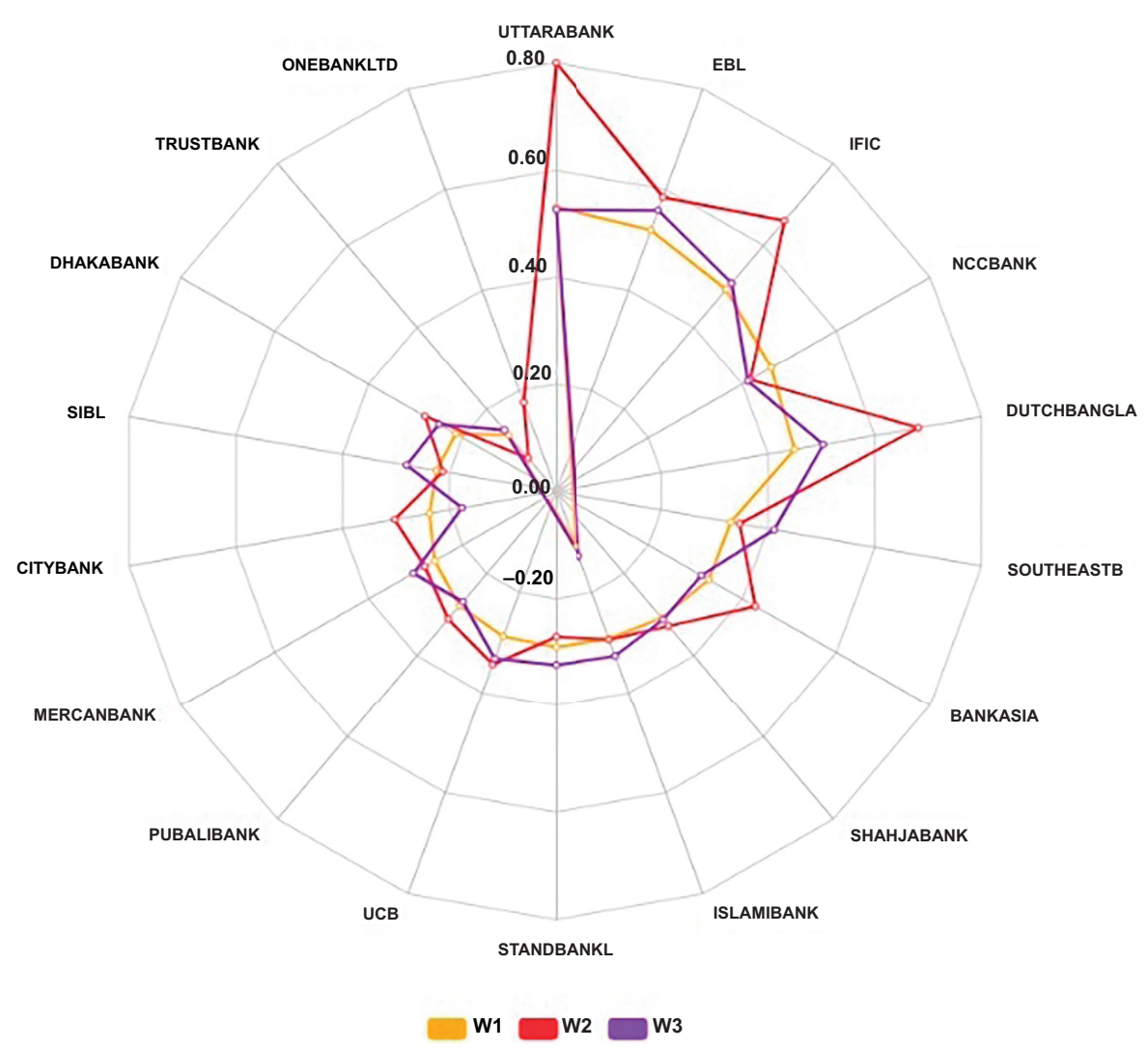

ONEBANK is the least resilient bank to the potential negative effects caused by the COVID-19 pandemic. ONEBANK has scored last in all rankings. In very extreme, the aggregate value or performance score under HELLWIG method may go beyond the regular interval $[0,1]$ (Müller-Fraczek, 2018). In case of ONEBANK, performance value has been negative in most under-Hellwig method. This signifies the extreme or low resistance capacity of ONEBANK amid adverse economic effects of COVID-19 pandemic. Besides, CITYBANK, TRUSTBANK, STANDBANKL, SIBL and DHAKABANK have maximum lowest scores in all rankings; UCB, ISLAMIBANK, SHAHJABANK, BANKASIA, MERCANBANK and PUBALIBANK have maximum moderate scores and EBL, DBBL, IFIC, SOUTHEASTB, UTTARABANK and NCCBANK have maximum top scores. This study has found EBL and DBBL to be the best resilient banks which is consistent with the findings reported by Adnan and Rahat (2020) (see Figures 3 and 4).

For checking robustness of the study, CRAR has been used instead of tier-1 capital ratio as a proxy of capital adequacy. Results are consistent with the main model then in most cases except for NCCBANK, DHAKABANK, UCB and ISLAMIBANK due to the variation in implementation of Basel-III in these banks. Under CRAR-based TOPSIS and HELLWIG analysis, the ranking of NCCBANK has fallen from top score to lowest score group, whereas the ranking of DHAKABANK has gone up from lowest score to moderate score group. Though NCCBANK's tier-1 capital adequacy ratio is higher and close enough to that of the other banks in top score category, its CRAR and other performance ratios are less compared 


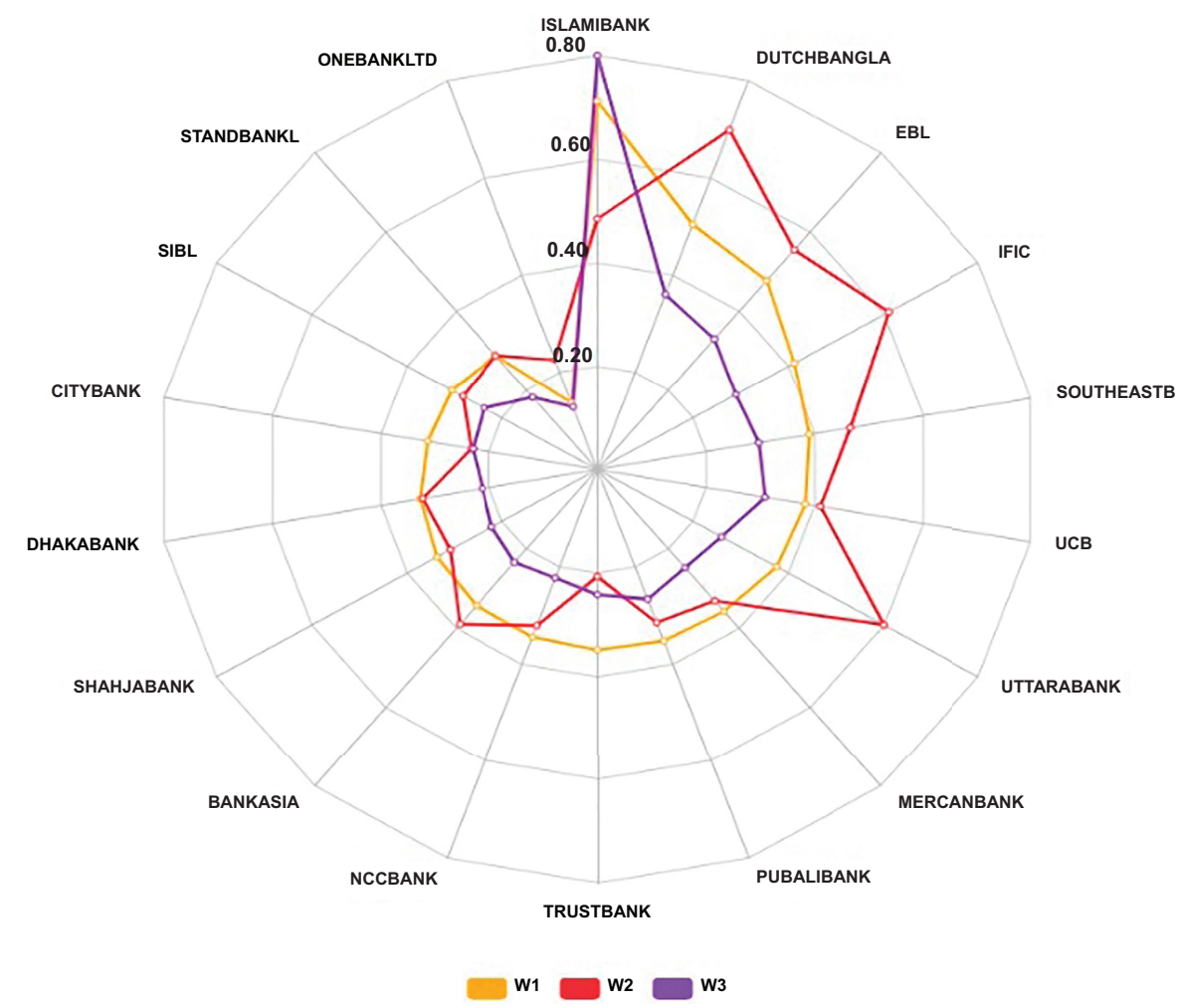

An application of MCDMbased approaches

291

Figure 3.

Resilience of assessed banks under-option 2 and TOPSIS method

to that of those banks, which has caused it lower ranking in the latter case. On the other hand, DHAKABANK could upgrade its position by one category, as its CRAR is significantly larger than its tier-1 capital ratio because of Basel III implementation. Besides, ISLAMIBANK has remained in moderate category though its two moderate ranking scores downgraded to lowest ranking scores due to lower CRAR than other banks in that category. At the same time, UCB has secured its position in top score due to higher CRAR than ISLAMIBANK though both banks are in moderate category in tier-1 based capital adequacy model. Adnan and Rahat (2020) ranked CITYBANK and TRUSTBANK among top 10 banks and IFIC and UTTARABANK got ranking at the bottom level of the 30 banks list, whereas this study has ranked the earlier two banks among lowest score group and the latter two banks among top score group. This study has given high weights in short-term liquidity ratio (Z2 variable) in both "Option 1" and "Option 2". CITYBANK and TRUSTBANK have the lowest short-term liquidity ratio ( $Z 2$ variable) which outweighed their better values in other performance indicators. Similarly, IFIC and UTTARABANK have high liquidity ratio compared to others, which offset their other poor performance indicators. Moreover, UTTARABANK has the lowest credit risk exposure due to its less loan share in the industries which are adversely affected by the COVID-19 pandemic.

\section{Conclusion and policy implications}

The COVID-19 pandemic has slowed down economic growth and caused many businesses to shut down. As it has triggered adverse economic events, financial institutions will face severe 
AJAR
6,3

292

Figure 4.

Resilience of assessed banks under-option 2 and HELLWIG method

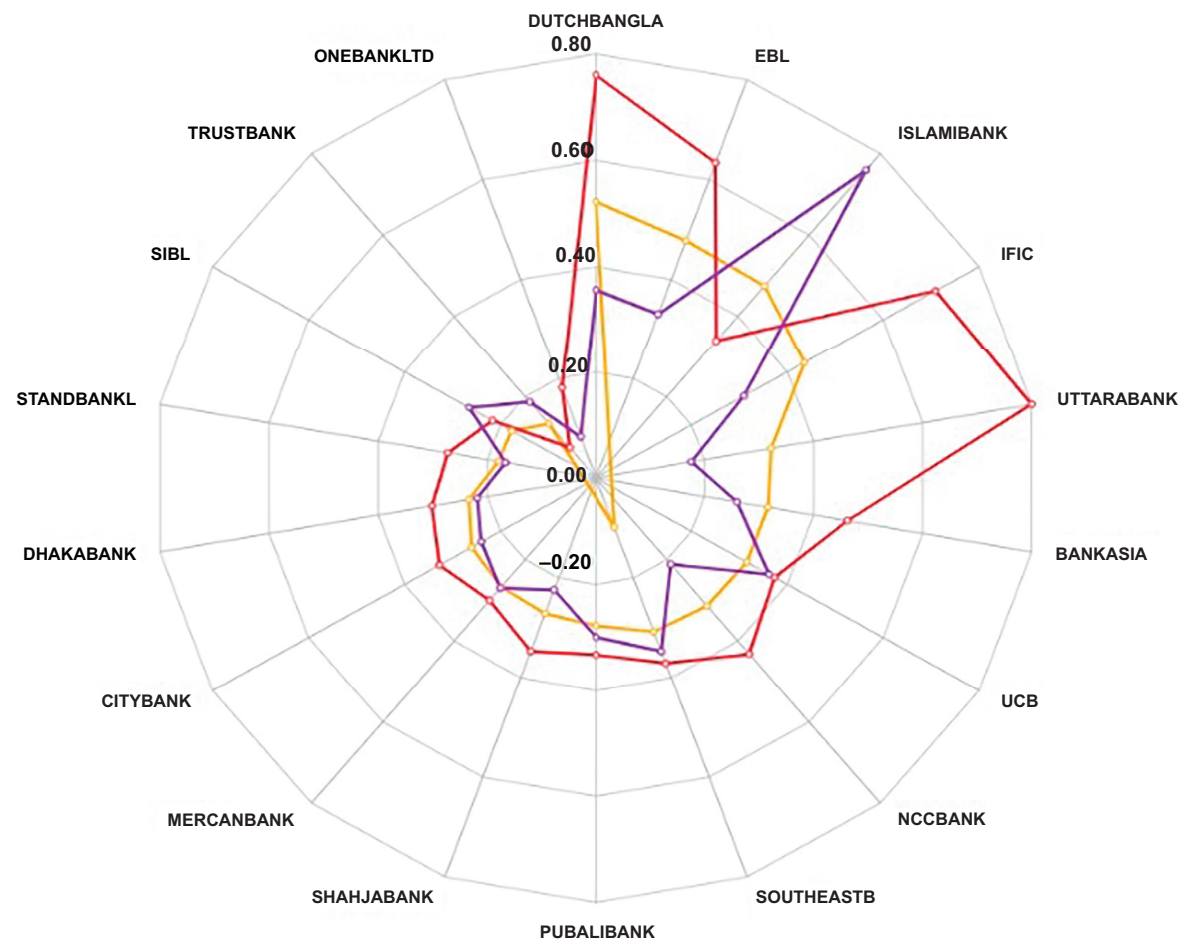

W1

w2 W3

consequences of this shock. It is found that EBL and DBBL are the most resilient banks in Bangladesh in managing negative effects of the COVID-19 pandemic. Moreover, it can be concluded that ONEBANK, CITYBANK, TRUSTBANK, STANDBANKL, SIBL and DHAKABANK are the least resilient banks in Bangladesh to the negative impact of COVID-19 pandemic. Banks with low-capital adequacy, low-liquidity ratio, high-NPLs ratio, low profitability and loan exposure to risky sectors are more vulnerable irrespective of the bank size. Some of those above banks have considerable profitability ratio but low-capital base, high NPLs and low-short-term liquidity ratio. CITYBANK and TRUSTBANK have the lowest short-term liquidity ratio (less than 1) and high-NPLs ratio that offset the impact of their high value in profitability. Therefore, banks should concentrate on maintaining not only high-capital base but also low NPLs and high-liquidity ratio which is most necessary during COVID-19 outbreak as demand of money will increase significantly. Moreover, this study has found that banks having high loan concentration in the industrial sectors negatively affected by COVID-19 can survive this crisis period if they can maintain capital base (both tier-1 and tier-2) more than the required level, highest short-term liquidity and lowest possible NPLs. Despite having large share in loan disbursement in risky sectors, EBL and DUTCHBANGLA are backed by the highest short-term liquidity ratio and profitability ratio which ultimately help these banks to get the highest performance scores in TOPSIS and HELLWIG.

This pandemic has come with lots of uncertainty and no one is sure how long and to what extent this will affect the whole economy. The banking sector of Bangladesh has already been facing a deep crisis due to severe corruption and granting loans on political inclination. 
Steps should be taken to the policy level which must be implemented and monitored strictly by the authority to control the growing NPLs. Top loan defaulters should be brought to account to collect the defaulted loan money and banks should be prudent enough in rescheduling the loan payments of top defaulters. Bankers must also deal in banking activity honestly and disclose all relevant information. Many banks do not disclose information of counterparty type credit exposure in detail. All the banks should present and disclose counterparty type credit exposure information in a manner that will promote transparency, consistency and comparability. The policymakers should also investigate and address this crucial issue so that investors, regulators and other stakeholders can utilize this publicly available financial information for the designated purposes. This study also calls for the application of IFRS 9, which is very much relevant in existing pandemic situation but not widely implemented in Bangladeshi banking sector till now. The method applied in the study can serve as a decision-making tool for investment and facilitate supervision of financial health of the banking sector. Besides, findings of this study will give an insight into the strength of the banking sector's credit exposure during the COVID-19 pandemic. However, these findings are based on certain estimates amid the COVID-19 pandemic. Relevant judgments and evidence are used while forecasting probable economic shocks for banks. Besides, all the listed banks could not be taken due to variations in the disclosure of loan classification in the annual report. Future research can address the resilience of banks after the COVID-19 pandemic with large sample size, real-time data and different relevant diagnostic methods.

\section{References}

Adnan, H. and Rahat, M. (2020), "EBL Dutch-bangla and brac bank on top", Banik Barta, August 23, available at: https://bonikbarta.net/home/news_description/239106/ (accessed 16 September 2020).

Aldasoro, I., Fender, I., Hardy, B. and Tarashev, N. (2020), "Effects of COVID-19 on the banking sector: the market's assessment”, BIS Bulletin, Vol. 12, Article No. 12, pp. 1-9.

Asian Tiger Capital (2020), Bangladesh Banking Sector Report, Asian Tiger Capital Research, available at: https://www.arx.cfa/-/media/regional/arx/post-pdf/2020/07/11/at-capitalbangladesh-banking-sector-report.ashx?la =en\&hash=1EC1487BDA3DAD98B7BB96312 6441A541915F388 (accessed 14 December 2020).

Bakir, C. (2013), Bank Behavior and Resilience: The Effect of Structures, Institutions and Agents, Palgrave Macmillan, London. doi: 10.1057/9781137308160_3.

Bangladesh Bank (2020), "Loan extension”, available at: https:/www.bb.org.bd/mediaroom/circulars/ brpd/sep282020brpd17.pdf (accessed 1 September 2020).

Bank for International Settlements (2009a), "Strengthening resilience of the banking sector", available at: https://www.bis.org/publ/bcbs164.pdf (accessed 11 October 2020).

Bank for International Settlements (2009b), "Comprehensive response to the global banking crisis", available at: https://www.bis.org/press/p090907.htm (accessed 11 October 2020).

Barua, B. and Barua, S. (2020), "COVID-19 implications for banks: the case of an emerging economy", SN Business Economics Journal, Vol. 1, Article Number 19.

Bryan, J., Clempner, J. and Low, S. (2020), "The role of retail banks in fighting COVID-19”, Oliver Wyman, available at: https://www.oliverwyman.com/our-expertise/insights/2020/apr/covid-19retailbanking.html (accessed 11 October 2020).

Fura, B. and Wang, Q. (2017), "The level of socioeconomic development of EU countries and the state of ISO 14001 certification”, Quality and Quantity, Vol. 51 No. 1, pp. 103-119.

Görg, H., Krieger-Boden, C. and Nunnenkamp, P. (2020), "Poor countries have the least developed financial systems - that has to change", World Economic Forum, available at: https://www.
An application of MCDMbased approaches

293 
AJAR 6,3 weforum.org/agenda/2016/08/poor-countries-have-the-least-developed-financial-systems-thathas-to-change/ (accessed 4 October 2020).

Goodell, J.W. (2020), “COVID-19 and finance: agendas for future research”, Finance Research Letters, Vol. 35, 101512, doi: 10.1016/j.frl.2020.101512.

Han, R. and Melecky, M. (2013), "Financial inclusion for financial stability", Access to Bank Deposits and the Growth of Deposits in the Global Financial Crisis (Policy Research Working Paper No. 6577), The World Bank, Washington, District Columbia.

Hellwig, Z. (1968), "Zastosowania metody taksonomicznej do typologicznego podziału krajów ze wzgledu na poziom rozwoju i strukture wykwalifikowanych kadr”, Przeglad Statystyczny, Vol. 4, pp. 307-327.

Hossain, S. (2020), "Default loans rise Tk3,606cr amid pandemic", The Business Standard, August 23, available at: https://tbsnews.net/economy/default-loans-rise-tk3606cr-amid-pandemic-123277? (accessed 4 October 2020).

Huang, R. and Ratnovski, L. (2009), "Why are Canadian banks more resilient?", IMF Working Papers 09/152, International Monetary Fund, available at: https:/www.imf.org/external/pubs/ft/wp/ 2009/wp09152.pdf (accessed 10 October 2020).

Korzeb, Z. and Niedziółka, P. (2020), "Resistance of commercial banks to the crisis caused by the COVID-19 pandemic: the case of Poland", Equilibrium. Quarterly Journal of Economics and Economic Policy, Vol. 15 No. 2, pp. 205-234, doi: 10.24136/eq.2020.010.

Korzeb, Z. and Samaniego-Medina, R. (2019), "Sustainability performance. A comparative analysis in the polish banking sector", Sustainability, Vol. 11 No. 3, pp. 653-669.

LankaBangla Asset Management Company Limited (2020), "COVID-19 impact on Bangladesh economy", Asia-Pacific Research Exchange, available at: https://www.arx.cfa/en/research/2020/ 06/soc290620-covid-19-impact-on-bangladesh-economy (accessed 14 December 2020).

Maheswaran, M. and Rao, D.N. (2014), "Stress test for risk assessment under Basel framework applied in banking industry", Risk Governance and Control: Financial Markets and Institutions, Vol. 4 No. 3, pp. 25-29, doi: $10.22495 /$ rgcv4i3art3.

McKibbin, W. and Fernando, R. (2020), The Global Macroeconomic Impacts of COVID-19: Seven Scenarios (No. 2020-19), Centre for Applied Macroeconomic Analysis, Crawford School of Public Policy, The Australian National University, Canberra.

Ministry of Finance (2019), "Budget speech 2019-2020", available at: https://mof.portal.gov.bd/sites/ default/files/files/mof.portal.gov.bd/page/ca4218f7_7fe3_4e9a_afd4_5eb7dc7c0477/Budget\% 20Speech\%202019-20\%20English.pdf (accessed 11 October 2020).

Mousavi-Nasab, S.H. and Sotoudeh-Anvari, A. (2017), "A comprehensive MCDM-based approach using TOPSIS, COPRAS and DEA as an auxiliary tool for material selection problems", Materials and Design, Vol. 121, pp. 237-253.

Müller-Frączek, I. (2018), "Dynamic measure of development”, The 12th Professor Aleksander Zelias International Conference on Modelling and Forecasting of Socio-Economic Phenomena, pp. 326-334. doi: 10.14659/SEMF.2018.01.33.

Nakatani, R. (2020), "Macroprudential policy and the probability of a banking crisis", Journal of Policy Modelling, Vol. 42 No. 6, doi: 10.1016/j.jpolmod.2020.05.007.

Patra, B. and Padhi, P. (2020), "Resilience of Indian banks: macroeconomic stress test modeling for Indian banks", Journal of Public Affairs, Vol. e2350, doi: 10.1002/pa.2350.

Reeves, M. and Whitaker, K. (2020), "A guide to building a more resilient business", Harvard Business Review, available at: https://hbr.org/2020/07/a-guide-to-building-a-more-resilient-business (accessed 3 October 2020).

Roy, S. and Das, A. (2018), "Application of TOPSIS method for financial performance evaluation: a study of selected scheduled banks in Bangladesh", Journal of Commerce and Accounting Research, Vol. 7 No. 1, p. 24. 
Selvan, S.A. and Vivek, N. (2020), "Impact of COVID-19 on the Indian banking sector", Purakala, Vol. 31, pp. 129-133.

Shammi, M., Bodrud-Doza, M., Islam, A. and Rahman, M. (2020), "Strategic assessment of COVID-19 pandemic in Bangladesh: comparative lockdown scenario analysis, public perception, and management for sustainability", Environment, Development and Sustainability, pp. 1-44.

Shiller, R.J. (2020), "COVID-19 has brought about a second pandemic: financial anxiety", World Economic Forum, available at: https://www.weforum.org/agenda/2020/04/pandemicscoronavirus-covid19-economics-finance-stock-market-crisis (accessed 4 October 2020).

The Business Standard (2020), "11 banks face provision shortfall", The Business Standard, August 24, available at: https:/tbsnews.net/economy/banking/11-banks-face-provision-shortfall-123763? (accessed 6 October 2020).

Wilson, E. (2020), “Coronavirus is cost and opportunity for Asia's banks”, Euromoney, March 02, available at: https://www.euromoney.com/article/b1k14kc07s51cv/coronavirus-is-cost-andopportunity-for-asias-banks (accessed 25 September 2020).

World Bank (2020a), COVID-19 to Plunge Global Economy into Worst Recession since World, World Bank, Washington.

World Bank (2020b), "COVID-19 outbreak: capital markets implications and response”, World Bank, available at: http://pubdocs.worldbank.org/en/776691586478873523/COVID-19-OutbreakCapital-Markets.pdf (accessed 5 October 2020).

\section{Further reading}

War II, May 11, World Bank, available at: https:/www.worldbank.org/en/news/press-release/2020/06/ 08/covid-19-to-plunge-global-economy-into-worst-recession-since-world-war-ii (accessed 6 October 2020).

\section{Appendix}

Appendixes of this article are included in a supplementary document which is available at: https://drive. google.com/file/d/14OKfWUTy7bcvKybtzDWD7wt21OtJs-4y/view?usp=sharing

\section{Corresponding author}

Ratan Ghosh can be contacted at: ratanghosh18@gmail.com

\section{An application of MCDM- based approaches}

For instructions on how to order reprints of this article, please visit our website:

www.emeraldgrouppublishing.com/licensing/reprints.htm

Or contact us for further details: permissions@emeraldinsight.com 